\title{
PENGARUH KEPEMIMPINAN DAN MOTIVASI ANAK ASUH TERHADAP KESEJAHTERAAN SOSIAL ANAK ASUH DI PANTI ASUHAN KURNIA ASIH BANDUNG
}

\author{
${ }^{1}$ Agus Bagianto ${ }^{2}$ Yuniati \\ ${ }^{1}$ Sekolah Tinggi Ilmu Ekonomi Muhammadiyah Bandung, Indonesia \\ agusbagianto@stiemb.ac.id \\ ${ }^{2}$ Sekolah Tinggi Ilmu Ekonomi Muhammadiyah Bandung, Indonesia \\ yuniati@stiemb.ac.id
}

\begin{abstract}
Abstrak
Penelitian ini dilaksanakan di Panti Asuhan Kurnia Asih. Masalah yang dirumuskan meliputi adakah pengaruh kepemimpinan terhadap kesejahteraan sosial anak asuh dan adakah pengaruh motivasi anak asuh terhadap kesejahteraan anak asuh di Panti Asuhan Kurnia asih. Serta adakah pengaruh kepemimpinan bersama-sama motivasi anak asuh terhadap kesejateraan sosial anak asuh di Panti Asuhan Kurnia Asih.

Metode penelitian yang digunakan adalah metode deskriptif analisis dan pengoperasian penghitungannya mengunakan SPSS.16 dilakukan terhadap seluruh anak asuh sebanyak 50 anak dijadikan sebagai responden. Teknik analisis yang digunakan yaitu teknik analisis statistik descriptif cross tabulation dilihat dari jenis kelamin dan usia dan analisis statistik mean one-way anova dilihat dari jenjang pendidikan dan status anak asuh. Kemudian untuk mengetahui derajat keeratan hubungan antara variabel penelitian menggunakan analisis korelasi dan regresi linier sederhana dan teknik analisis jalur (path analisis).

Hasil penelitian menunjukkan bahwa variabel kepemimpinan, motivasi anak asuh dan kesejahteraan sosial anak asuh kesemuanya berada pada kategori penilaian sangat baik dari responden. Terdapat pengaruh positif yang signifikan antara kepemimpinan (X1) terhadap kesejahteraan sosial anak asuh (Y) di Panti Asuhan Kurnia Asih, sebesar 0,391 atau 39,1\%. Terdapat pengaruh positif yang signifikan antara motivasi anak asuh (X2) terhadap kesejahteraan sosial anak asuh di Panti Asuhan Kurnia Asih, sebesar 0,413 atau 41,3\%. Terdapat pengaruh positif yang signifikan antara kepemimpinan (X1) dan motivasi anak asuh (X2) secara bersama-sama/simultan terhadap kesejahteraan sosial anak asuh di Panti Asuhan Kurnia Asih, sebesar 0,545 atau 54,5\%.

Kesimpulan dari penelitian ini adalah terbukti ada pengaruh yang signifikan antara kepemimpinan (X1) dan motivasi anak asuh (X2) terhadap kesejahteraan sosial anak asuh (Y) di Panti asuhan Kurnia Asih.
\end{abstract}

Kata Kunci : Kepemimpinan, Motivasi anak asuh, dan Kesejahteraan sosial anak asuh. 


\section{Abstract}

The research was done at Kurnia Asih Orphanage in Bandung. The cases was formulated as follow : are there the influence of leadership to ward the social welfare of the foster child and are there the influence of motivation of the foster child to ward the social welfare of the foster child, then are there the influence of leadership and the motivation of a foster child as simultanously to ward the social welfare of a foster child at Kurnia Asih Orphanage.

The research methode used descriptive analysis and the application to operate has been used by SPSS.16 with the 50 population as respondent for all children who live in Kurnia Asih Orphanage. The data analysis technique has been used the cross tabulation statistic analysis to be seen from gender and the age of children and means one-way anova to be seen from levels of education and the status of the child. Then used the correlation analysis technique to know about correlationship degree among the research variabel and path analysis technique.

The research of result that the leadership, motivation of the foster child and sosial welfare of the foster child variable is the best category. There are the influential a significant positive the leadership (X1) toward the social welfare of a foster child (Y) at Kurnia Asih Orphanage, has got 0,391 or 39,1\%. There are the the influential a significant positive the motivation of a foster child (X2) toward the social welfare of a foster child (Y) at Kurnia Asih Orphanage, has got 0,413 or 41,3\%. there are the influence of leadership (X1) and the motivation of a foster child (X2) as simultanously to ward the social welfare of a foster child (Y) at Kurnia Asih Orphanage, has got 0,545 or 54,5\%.

The Conclusion from this research is proved the influential a significant positive between the leadership (X1) and the motivation of the foster child (X2) toward social welfare of the foster child (Y) at Kurnia Asih Orphanage.

Key Word: The leadership, the motivation of the foster child, and the social welfare of the foster child.

\section{PENDAHULUAN}

Penelitian ini memberikan gambaran tentang kehidupan anak-anak di panti dan di luar panti. Sisi kehidupan yang dianggap menyenangkan diantaranya adalah banyak teman sedangkan yang menyedihkan umumnya adalah karena terpisah jauh dari keluarga, makanan yang buruk, keharusan bekerja di panti asuhan/LKSA dan aturan yang ketat. Hal yang tidak kalah pentingnya adalah kehidupan mereka di sekolah. Selain menjadi impian semua anak yang terlibat dalam penelitian, sekolah menghadapkan mereka pada kekhawatiran tentang masa depan mereka. Umumnya anak-anak mencemaskan kondisi setelah mereka menyelesaikan SLTA. Keterbatasan dukungan dan motivasi dari pimpinan pada saat mereka di panti asuhan/LKSA, 
ketidakdekatan dengan keluarga dan kehilangan teman di lingkungan rumah panti dan saat harus keluar panti, membuat anak-anak bingung dan cemas. Salah satu penyebabnya adalah kurang adanya motivasi dari pimpinan dan pengelola panti asuhan. Hal tersebut sebagian karena kepemimpinan yang belum dapat memotivasi dan mensejahterakan anggota anak-anak asuhnya secara memadai karena dengan segala keterbatasannya dan dukungan dari pemerintah secara intensif. Mengapa terjadi demikian? menandakan bahwa kepemimpinan dalam suatu negara ataupun organisasi begitu sangat penting, karena sangat berdampak pula pada tujuan dari negara atau organisasi itu sendiri, yakni tujuan untuk memotivasi dan mensejahterakan anggotanya khususnya bagi organisasi sosial seperti Panti Asuhan Kurnia Asih. (Standar Nasional Pengasuhan untuk LKSA,2011:4)

Gambaran-gambaran di atas menjadi suatu hal yang melatar belakangi kami sebagai peneliti, apakah betul di setiap panti asuhan, kepemimpinan dan motivasi anak asuh berpengaruh terhadap kesejahteraan sosial anak asuh, namun peneliti hanya akan meneliti scope organisasi yang lebih kecil yaitu organisasi Panti Asuhan Kurnia Asih.
Apakah terdapat pengaruh antara kepemimpinan dan motivasi anak asuh terhadap kesejahteraan sosial anak asuh di Panti Asuhan Kurnia Asih. Berdasarkan hal tersebut di atas peneliti merasa tertarik untuk meneliti tentang : "Pengaruh Kepemimpinan dan Motivasi Anak Asuh terhadap Kesejahteraan Sosial Anak Asuh di Panti Asuhan Kurnia Asih ”

\section{Rumusan Masalah}

Dari pertanyaan masalah pokok tersebut, maka sub-sub pertanyaan masalah dalam penelitian ini sebagai berikut :

1. Apakah terdapat pengaruh kepemimpinan terhadap kesejahteraan sosial anak asuh di Panti Asuhan Kurnia Asih.

2. Apakah terdapat pengaruh motivasi anak asuh terhadap kesejahteraan sosial anak asuh di Panti Asuhan Kurnia Asih.

3. Apakah terdapat pengaruh kepemimpinan dan motivasi anak asuh secara bersamasama terhadap kesejahteraan sosial anak asuh di Panti Asuhan Kurnia Asih.

\section{Tujuan Penelitian}

1. Ingin mengetahui apakah terdapat pengaruh kepemimpinan terhadap 
kesejahteraan sosial anak asuh di Panti Asuhan Kurnia Asih.

2. Ingin mengetahui apakah terdapat pengaruh motivasi anak asuh terhadap kesejahteraan sosial anak asuh di Panti Asuhan Kurnia Asih.

3. Ingin mengetahui apakah terdapat pengaruh kepemimpinan dan motivasi anak asuh secara bersamasama terhadap kesejahteraan sosial anak asuh di Panti Asuhan Kurnia Asih.

\section{Kegunaan Penelitian}

Adapun kegunaan penelitian ini adalah sebagai berikut :

\section{Secara Teoretis :}

Hasil penelitian ini diharapkan dapat memberikan sumbangan dan bahan masukan bagi pemerintah dan sebagai kritis sosial yang akan menggugah hati nurani seorang pemimpin. Untuk dijadikan contoh yang baik dalam hal kepemimpinan yang amanah dalam upaya memotivasi dan mensejahterakan anak asuhnya dan sebagai bahan referensi bagi panti asuhan/LKSA dalam menjalankan kepemimpinan di panti asuhan.

\section{Secara Praktis :}

Memecahkan permasalahan praktis dari rantai permasalahan kepemimpinan, motivasi anak asuh dan kesejahteraaan sosial anak asuh di panti asuhan-panti asuhan.

\section{Secara Akademik :}

Penelitian ini dapat dijadikan sumber acuan bagi para peneliti lainnya yang ingin mengungkapkan permasalahan kepemimpinan, motivasi anak asuh dan kesejahteraaan sosial anak asuh.

\section{TINJAUAN LITERATUR}

Kepemimpinan Transforming Anderson

Perilaku kepemimpinan transforming menurut Anderson (1998) ialah visi, perencanaan, komunikasi dan tindakan kreatif yang memiliki efek positif pada sekelompok orang dalam sebuah susunan nilai dan keyakinan yang jelas, untuk mencapai tujuan yang telah ditetapkan dengan jelas dan dapat diukur. Banyak pemimpin yang tidak memenuhi salah satu di antara lima keterampilan yang dibutuhkan dalam perilaku kepemimpinan transforming, yaitu:

a. Manajemen Diri: 1) persiapan, 2) pemusatan, 3) klarifikasi/kejelasan keyakinan, 4) spesifikasi tujuan, 5) identifikasi nilai-nilai, 6) perencanaan 
hidup, 7) penyusunan tujuan pendidikan, 8) penyusunan tujuan karir, 9) manajemen waktu 10) manajemen stres/tekanan, 11) manajemen kesehatan, dan 12) perilaku mental yang positif. b. Komunikasi Interpersonal : 1) keterbukaan diri, 2) manajemen khayalan, 3) manajemen impresi, 4) kehadiran, 5) observasi, 6) menunda, 7) menanyakan, 8) mendengarkan, 9) menanggapi, 10) percaya diri, 11) konfrontasi, dan 12) menentang

c. Pembimbingan dan Manajemen Masalah : 1) empati lebih awal, 2) eksplorasi masalah, 3) spesifikasi masalah, 4) kepemilikan masalah, 5) penyusunan tujuan, 6) kepemilikan tujuan, 7) perencanaan tindakan, 8) pelaksanaan rencana aksi, 9) konfrontasi, 10) saling berbagi, 11) kedekatan, dan 12) pemindahan.

d. Tim dan Pengembangan Organisasi : 1) penilaian informal, 2) penilaian formal, 3) fasilitasi manajemen masalah, 4) klarifikasi/kejelasan kebutuhan, 5) pemeriksaan kesiapan, 6) penempatan nilai-nilai, 7) pembentukan konsensus, visi, 8) pembentukan konsensus strategi, 9) penyusunan program, 10) evaluasi kinerja, 11) peningkatan yang berkesinambungan, dan akuntabilitas. e. Luwes dalam gaya, peran, dan keterampilan : 1) penilaian gaya personal, 2) perubahan gaya, 3) penilaian peran, 4) perubahan peran, 5) pengakuan tahaptahap perkembangan organisasi, dan 6) fasilitas tahap-tahap pengembangan organisasi.

12 Prinsip yang menjadi inti dari perilaku kepemimpinan transforming menurut Anderson dalam Usman Husaini (2006:288), yaitu sebagai berikut:

1) Setiap orang dalam situasi apa pun mempunyai pengaruh, baik ataupun buruk.

2) Dengan belajar mengamati pengaruh ini akan membuat kita waspada terhadap kenyataan akan adanya kesempatan dan kejadian positif dan negatif.Meningkatkan kewaspadaan terhadap orang dan kejadian akan sangat berguna bagi setiap orang.

3) Setiap orang boleh memilih untuk mencoba dan membuat perubahan yang positif setiap saat.

4) Penggunaan kekuasaan secara positif dan bertanggung jawab serta pengaruh sangat penting dalam menciptakan kepemimpinan yang efektif. Dengan mengetahui kekuatan sendiri, mengambil posisi yang strategis, melakukan kerja sama dengan orang yang satu pemikiran, 
serta mengomunikasian kekuasaan anda dalam cara yang positif akan mambantu anda untuk mancapai tujuan utama.

5) Segala hal bermula dari inisiatif setiap individu. Secara pribadi dan tersembunyi, setiap orang menentukan dalam diri mereka masing-masing hal-hal yang akan dilakukan dan bagaimana memperlakukan orang lain.

6) Kepemimpinan, dalam artian yang lebih mendalam adalah pemahaman dan pemenuhan kebutuhan utama dari orang yang sedang kita pimpin/layani. Bagaimanapun peningkatan inovasi dan produktivitas dari tujuan yang akan dicapai, perlu juga diperhatikan kebutuhan tiap orang akan pengakuan, penghargaan, dan pencapaiannya. Untuk mendorong motivasi dan kepuasan.

7) Transformasi kepemimpinan memiliki komponen moral yang sangat penting dalam segala aspek kepemimpinan. Biasanya hanya sedikit orang yang mau percaya kepada pemimpin yang pernah berdusta, menyalahgunakan wewenang, ataupun menyakiti orang lain sebelumnya.

8) Transformasi kepemimpinan selalu memahami dan melibatkan orang lain sehingga tercapai rasa saling memiliki dan saling menghormati serta mempercayai. Hal ini akan semakin meningkatkan motivasi, moral, kreativitas, energi, dan produktivitas.

9) Selalu ada kesempatan bagi kepemimpinan disegala lingkungan,interaksi,situasi, dan setiap saat. Kepemimpinan bertujuan untuk membuat perubahan yang positif dalam perkembangan organisasi dan individu untuk tujuan yang lebih spesifik.

10) Transformasi kepemimpinan memiliki pengaruh dalam perkembangan jangka panjang.

11) Transformasi kepemimpinan bermula dari dalam keyakinan dan struktur nilai seseorang. Tujuan dan misi hidup yang penting bagi kepemimpinan juga perlu dipertahankan.

Transformasi kepemimpinan selalu terbuka akan potensi pemahaman yang lain yang lebih mandalam atau lebih tinggi terhadap kenyataan di masa depan dibandingkan dengan kenyataan yang ada saat ini.

Teori McCleilland

McCleilland mengetengahkan teori motivasi yang berhubungan erat dengan teori belajar. McCleilland (1962) berpendapat bahwa banyak kebutuhan yang diperoleh dari kebudayaan. Tiga 
dari Kebutuhan McCleilland ialah 1) kebutuhan akan prestasi (need of achievement) disingkat $\mathrm{n}$ Ach, 2) kebutuhan akan afiliasi disingkat n Aff, dan 3) kebutuhan akan kekuasaan (need of power) disingkat $\mathrm{n}$ Pow.

Motivasi berprestasi ialah dorongan dari dalam diri untuk mengatasi segala tantangan dan hambatan dalam upaya mencapai tujuan. Motivasi afiliasi ialah dorongan untuk berhubungan dengan orang lain atau dorongan untuk memiliki sahabat sebanyak-banyaknya. Motivasi berkuasa ialah dorongan untuk mempengaruhi orang lain agar tunduk kepada kehendaknya.

McCleilland juga mengetengahkan bahwa jika kebutuhan seseorang terasa sangat mendesak maka kebutuhan itu akan memotivasi orang untuk berusaha keras memenuhinya. Alat untuk mengukur $\mathrm{n}$ Ach telah dikembangkan oleh Murray (1943) dengan nama Thematic Apperception Test (TAT) yang berisikan gambar-gambar. Kemudian alat itu dikembangkan oleh McCleiland (1953) dengan memberikan nilai angka. Satu ciri penting $\mathrm{n}$ Ach ialah kebutuhan itu dapat dipelajari. N Ach yang mulanya rendah, setelah mendapat pelatihan atau pengalaman akan meningkat. McCleiland juga mengatakan bahwa bangsa yang dalam keadaan ekonomi terbelakang dapat ditingkatkan secara dramatis dengan merangsang rakyatnya untuk berprestasi tinggi.

Penelitian tentang motivasi menghasilkan konsep-konsep antara lain 1) manusia dewasa yang sehat penuh potensi. Walaupun potensi yang dimiliki manusia sudah tinggi, namun tanpa adanya motivasi untuk memanfaatkannya, maka ia tidak akan berprestasi. 2) manusia dewasa mempunyai sejumlah motif (kebutuhan dasar) yang menyalurkan potensinya. 3) manusia dewasa memenuhi kebutuhan sesuai dengan kebudayaannya. 4) Pemenuhan kebutuhan tampak pada perilakunya, orang yang bermotif tertentu akan berperilaku tertentu, 5) Perilaku yang tampak berbeda-beda tergantung situasinya.

Perilaku yang berhubungan dengan motif sosial dari McClelland menurut yang dikembangkan oleh tim Achievement Motivation Training (AMT) Massachuset memiliki indikator sebagai berikut :

Orang yang motif berprestasinya tinggi (Motif of Achievement) bercirikan :1)bertanggung jawab atas`segala 
perbuatannya, mengaitkan diri pada karir atau hidup masa depan, tidak manyalahkan orang lain dalam kegagalannya; 2) berusaha mencari umpan balik atas segala perbuatannya, selalu bersedia mendengarkan pendapat orang lain sebagai masukan dalam memperbaiki drinya;3) berani mengambil resiko dengan penuh perhitungan (menantang dan terwujud) melebihi orang lain, lebih unggul,ingin menciptakan yang terbaik;4) berusaha melakukan sesuatu secara inovatif dan kreatif (sasuatu yang baru, sesuatu yang tidak ada duanya), banyak gagasan dan mampu mewujudkan gagasan dengan baik. Ingin bebas berkarya, kurang menyenangi sistem yang membatasi geraknya ke arah yang lebih positif. Kekuatan datang dari tindakan anda sendiri bukan dari orang lain; 5) merasa dikejar-kejar waktu, pandai mengatur waktunya, yang dapat dikerjakan sekarang jangan ditunda hari esok, dan 6) bekerja keras dan bangga atas hasil kerja yang dicapai.

Orang yang motif bersahabatnya tinggi (motif of affiliation) bercirikan: 1) lebih suka bersama orang lain daripada sendirian; 2) sering berkomunikasi dengan orang lain; 3) lebih mengutamakan hubungan pribadi sendiri; 3)lebih mengutamakan hubungan pribadi daripada tugas kerja; 4) selalu bermusyawarah untuk mufakat dengan orang lain; 4) lebih efektif apabila bekerjasama dengan orang lain.

Orang yang motif berkuasanya tinggi (motif of power) bercirikan :1)Sangat aktif menentukan arah kegiatan organisasi;2) sangat peka terhadap pengaruh antar pribadi dan kelompok;3)mengutamakan prestise;4) mengutamakan tugas kerja daripada hubungan pribadi;5)suka memerintah dan mengancam dengan sanksi.

Berikut diterangkan mengenai kesejahteraan Sosial :

Kesejahteraan sosial adalah : kondisi terpenuhinya kebutuhan material, spiritual, dan sosial warga negara agar dapat hidup layak dan mampu mengembangkan diri, sehingga dapat melaksanakan fungsi sosialnya.(Undang-undang Republik Indonesia Nomor 11,2009:2)

Dari definisi diatas dapat ditarik kesimpulan sementara bahwa dimensi kesejahteraan menurut pengertian di atas adalah sebagai berikut:

1. Kebutuhan yang mendasar dalam hal materi contohnya : kebutuhan 
akan sandang, pangan, papan, istirahat, rekreasi, tidur.

2. Kebutuhan akan sprituil yakni kebutuhan akan keselamatan, rasa aman tentram hati.

3. Kebutuhan sosial yaitu kebutuhan akan berkelompok, bergaul, bermasyarakat, ingin dicntai serta ingin memiliki dan dimiliki.

\section{KERANGKA PENELITIAN}

$r \times 1 \times 2$

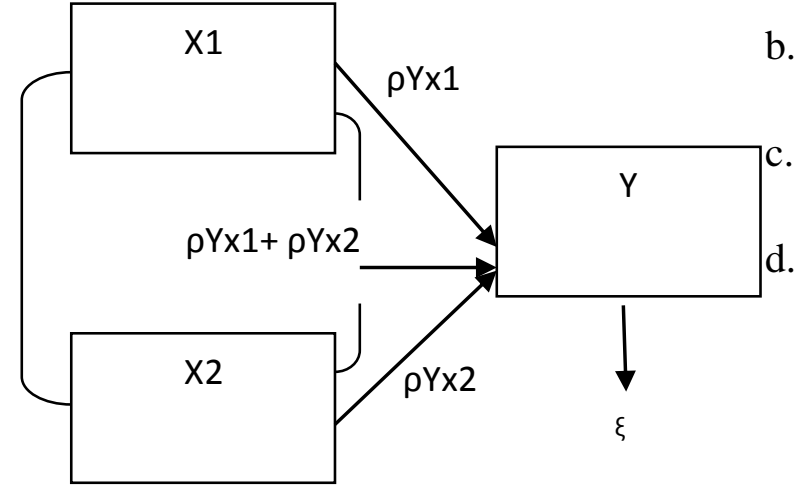

Gambar di atas dapat dijelaskan sebagai berikut :

Keterangan :

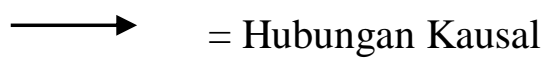

$\mathrm{X} 1=$ Kepemimpinan

X2 = Motivasi Anak

$\mathrm{Y} \quad=$ Kesejahteraan Sosial

Anak Asuh

Rho $(\rho)=$ Koefisien Jalur
$\operatorname{Alfa}(\alpha) \quad=$ Koefisien Korelasi

$\xi \quad=$ Variable tidak diuji

Persamaan Struktur yang dibentuk adalah :

1) $Y=\rho Y x 1+\rho y x 2+\xi$

a. Menghitung dan menyusun matrik koefisien korelasi (r) guna mengetahui korelasi variabel.

b. Menghitung koefisien jalur ( $\rho)$

Menghitung koefisien determinasi (r)

Menghitung koefisien jalur epsilon yang tidak diteliti melalui rumus :

$\operatorname{Py} \xi 1=\sqrt{1-R^{2} y(X 1)(X 2)}$

Gambar tersebut juga menggambarkan, apakah terdapat pengaruh kepemimpinan dan motivasi terhadap kesejahteraan sosial anak asuh, bagaimana pengaruhnya, penelitian ini dilaksanakan di Panti Asuhan Kurnia Asih berjumlah anak 50 anak panti asuhan. Peneliti ingin mengetahui pula apakah terdapat korelasi antara kepemimpinan dengan motivasi anak asuh. Selain itu terdapat faktor-faktor lain yang berpengaruh terhadap kesejahteraan yang peneliti tidak diuji, 
untuk menjadi rujukan peneliti lain apa yang membuat anak asuh dipanti asuhan sejahtera. Harapan penulis kerangka berpikir kami menjadi rujukan untuk peneliti berikutnya untuk meneliti dip anti-panti asuhan lainnya di Indonesia yang masih belum sejahtera.

\section{METODOLOGI PENELITIAN}

Penelitian yang kami gunakan adalah metode deskriptif analisis kuantitatif. Penelitian deskriptif kami bertujuan untuk memberikan gambaran permasalahan yang ada di Panti Asuhan Kurnia Asih yaitu tentang kepemimpinan, motivasi anak asuh selain itu untuk mengetahui pengaruhnya terhadap kesejahteraan sosial anak asuh di Panti Asuhan Kurnia Asih.

\section{Teknik Pengumpulan Data}

Teknik pengumpulan data yang dapat dilakukan dalam penelitian ini adalah :

1. Observasi atau pengamatan dilakukan dengan mengamati kondisi objektif panti asuhan untuk menjadi sampel penelitian.

2. Angket, teknik ini dilakukan dengan cara mengedarkan daftar pertanyaan tertutup (kuisioner) untuk diisi oleh responden anak asuh yang menjadi sampel dalam penelitian mengenai variabel kepemimpinan, motivasi anak asuh, dan kesejateraan sosial anak asuh.

3. Studi pustaka, teknik ini dilakukan untuk memperoleh informasi mengenai teori-teori yang relevan dengan permasalahan penelitian.

\section{Populasi dan Sampel}

Populasi yang sangat sedikit yakni hanya 50 anak maka pengambilan sampel yang dilakukan yaitu terhadap keseluruhan populasi anak asuh yakni 50 Anak Asuh.

\section{Alat Pengumpulan Data}

1. Pedoman observasi merupakan acuan yang digunakan pada saat melakukan pengamatan sehingga dapat sesuai dengan tujuan penelitian yang ingin dicapai, digunakan sebagai pedoman bagi peneliti.

2. Angket, berupa seperangkat pertanyaan tertutup dengan model skala ordinal perbedaan semantik. Setiap angket disusun sesuai dengan kebutuhan penelitian berkaitan dengan tema penelitian, dimana setiap variabel disusun sebanyak 15 
item pertanyaan yang diperuntukkan untuk anak asuh.

3. Dokumen berupa buku-buku primer maupun sekunder yang dinilai relevan dengan tema penelitian, karya ilmiah berupa hasil-hasil penelitian sebelumnya.

\section{Analisis Korelasi}

$$
\text { Untuk mengetahui derajat }
$$

4. keeratan antar variabel dengan menggunakan rumus:

$$
r x y=\frac{N \sum X Y-\left(\sum X\right)\left(\sum Y\right)}{\sqrt{\left\{\left(N \sum X^{2}-\left(\sum X\right)^{2}\right\}\left\{N \sum Y^{2}-(Y)^{2}\right\}\right.}}
$$

Peneliti menggunakan anilisis korelasi karena ingin mengetahui apakah terdapat pengaruh antar variabel yang sedang diteliti.

\section{Pengujian Hipotesis}

Hipotesis Simultan digunakan uji

F dengan rumus :

$$
\mathrm{F}=\frac{(n-k-I) R^{2} y x k}{k\left(-R^{2} y x k\right.}
$$

Kriteria uji, Ho ditolak jika nilai $\mathrm{F}$

hitung $\geq \mathrm{F}$ Table, dengan

demikian $\mathrm{H} 1$ diterima.
Hipotesis Parsial digunakan uji t dengan rumus :

$\mathrm{Tk}=\frac{P k}{S e P k} ;(d f=n-k-I)$

Kriteria Uji, Ho ditolak jika nilai $\mathrm{t}$ hitung $\geq \mathrm{t}$ tabel, dengan demikian H1 diterima. Sesuai dengan pernyataan Sugiyono(2004:61) bahwa Sampling jenuh adalah teknik penentuan sampel bila semua populasi dijadikan sampel. Karena penelitian ini menggunakan seluruh populasi yakni sebanyak 50 orang sebagai sampel atau responden adalah anak asuh di panti asuhan/LKSA “ Kurnia Asih. Analisis ini digunakan oleh peneliti dengan alasan untuk mengetahui terdapatkah pengaruh Kepemimpinan terhadap Motivasi dan Kesejehteraan Sosial Anak asuh, dengan kriteria uji sebagai berikut:

1)Tolak Ho dan H1 diterima jika tHitung>tTabel

2)Terima Ho dan H1 ditolak jika tHitung <tTabel 


\section{HASIL DAN DISKUSI}

\section{A.Analisis Korelasi antar Variabel}

Kepemimpinan (X1) dan Motivasi

Anak Asuh (X2)

Data yang telah terkumpul dari hasil kuisioner responden mengenai pernyataan kepemimpinan (X1), motivasi anak asuh (X2) diolah menggunakan software SPSS 16., manghasilkan output seperti tabel 4.34. dibawah ini:

\section{1}

Tabel korelasi antar kepemimpinan

(X), motivasi (X2) dan

kesejahteraan sosial anak $\operatorname{asuh}(\mathrm{Y})$

\begin{tabular}{|c|c|c|c|}
\hline & & $\begin{array}{c}\text { KEPEMIMPIN } \\
\text { AN }\end{array}$ & $\begin{array}{c}\text { MOTIVA } \\
\text { SI }\end{array}$ \\
\hline \multicolumn{4}{|c|}{ KEPEMIMPIN Pearson } \\
\hline \multirow[t]{5}{*}{ AN } & Correlati & 1 & $.687^{* *}$ \\
\hline & on & & \\
\hline & Sig. (2- & & \\
\hline & tailed) & & \\
\hline & $\mathrm{N}$ & 50 & 50 \\
\hline \multirow[t]{6}{*}{ MOTIVASI } & Pearson & & \\
\hline & Correlati & $.687^{* *}$ & 1 \\
\hline & on & & \\
\hline & Sig. (2- & חم0 & \\
\hline & tailed) & & \\
\hline & $\mathrm{N}$ & 50 & 50 \\
\hline
\end{tabular}

${ }^{* *}$. Correlation is significant at the 0.01 level (2tailed).

Sumber : Perhitungan SPSS

\section{Korelasi antara kepemimpinan (X) \\ dan Motivasi anak asuh (X2)}

Hasil output dapat dilihat bahwa korelasi kedua variabel bersifat signifikan karena angka signifikansinya sebesar 0,00<0,05.

Korelasi sebesar 0,687 mempunyai maksud hubungan antar variabel kepemimpinan (X) dan motivasi anak asuh (X2) kuat dan searah (karena hasilnya positif) . Searah artinya jika kepemimpinan (X1) baik maka motivasi anak asuh (X2) juga tinggi. Untuk menaksir harga korelasi digunakan kriteria sebagai berikut :

$0<\mathrm{r} \leq 0,25$ Korelasi sangat lemah

$0,25<\mathrm{r} \leq 0,5$ Korelasi Cukup

$0,5<\mathrm{r} \leq 0,75$ Korelasi Kuat

$0,75<\mathrm{r} \leq 1$ Korelasi sangat kuat

\section{B.Pengaruh Kepemimpinan (X1) dan}

Motivasi Anak Asuh (X2) terhadap

Kesejahteraan Sosial Anak Asuh (Y)

Untuk mengetahui pengaruh kepemimpinan (X1) dan motivasi anak asuh (X2) terhadap kesejahteraan sosial anak asuh mengunakan analisis regresi linier software SPSS 16. Menghasilkan Output seperti tabel 4.35, 4.36, 4.37. Di bawah ini: 


\section{Pengaruh Kepemimpinan (X1) dan}

Motivasi Anak Asuh (X2) Secara

Bersama-sama

Terhadap

Kesejahteraan Sosial Anak Asuh (Y)

Tabel 4.2

Model summary pengaruh kepemimpinan (X1) dan motivasi anak asuh (X2) terhadap kesejahteraan sosial anak asuh $(\mathrm{Y})$

\begin{tabular}{|l|r|r|r|r|}
\hline Model & \multicolumn{1}{|c|}{$\mathrm{R}$} & $\begin{array}{c}\mathrm{R} \\
\text { Square }\end{array}$ & $\begin{array}{c}\text { Adjusted R } \\
\text { Square }\end{array}$ & $\begin{array}{c}\text { Std. Error } \\
\text { of the } \\
\text { Estimate }\end{array}$ \\
\hline 1 & $.738^{\mathrm{a}}$ & .545 & .526 & 3.76398 \\
\hline
\end{tabular}

a. Predictors: (Constant), MOTIVASI,

KEPEMIMPINAN

Sumber : Perhitungan SPSS

Besarnya R Square ( r 2 ) didapat sebesar

0,545. Angka R square ini dapat

digunakan

untuk melihat besarnya pengaruh variabel $\mathrm{X} 1$ dan $\mathrm{X} 2$ terhadap $\mathrm{Y}$ secara bersamasama (simultan) dengan cara menghitung Koefisien Determinasi ( KD) dengan rumus

sebagai berikut :

$\mathrm{KD}=\mathrm{r} 2 \times 100 \%$

$=0,545 \times 100 \%$

$=54,5 \%$

Angka 54,5 \% mempunyai arti bahwa pengaruh $\mathrm{X} 1$ dan $\mathrm{X} 2$ secara bersamasama terhadap Y adalah sebesar 54,5\% dan sisanya sebesar 0,455 atau $\mathbf{4 5 , 5} \%$ karena pengaruh faktor lain.

\section{Tabel 4.3}

ANOVA $^{b}$

Pengaruh X1 dan X2 secara bersamasama terhadap Y

\begin{tabular}{|l|c|r|c|c|c|}
\hline Model & $\begin{array}{c}\text { Sum of } \\
\text { Squares }\end{array}$ & Df & $\begin{array}{c}\text { Mean } \\
\text { Square }\end{array}$ & F & Sig. \\
\hline 1 Regression & 798.544 & 2 & 399.272 & 28.182 & $.000^{a}$ \\
Residual & 665.876 & 47 & 14.168 & & \\
Total & 1464.420 & 49 & & & \\
\hline a. Predictors: (Constant),
\end{tabular}

MOTIVASI, KEPEMIMPINAN

b. Dependent Variable:

KESEJAHTERAAN

Sumber : Perhitungan SPSS

\section{Hipotesis :}

Ho : Tidak terdapat hubungan linier antara kepemimpinan (X1) dan motivasi anak asuh (X2) dengan kesejahteraan sosial anak asuh (Y)

H1 : Terdapat hubungan linier antara kepemimpinan (X1) dan motivasi anak asuh (X2) dengan kesejahteraan sosial anak asuh (Y)

\section{Menentukan $\mathbf{F}$ tabel :}

Taraf signifikansi 0,05 ;

$\mathrm{db}$ pembilang $=\mathrm{m}=\mathrm{jml}$ variabel bebas 1

$=2-1$

$=1$

df penyebut $=\mathrm{N}-\mathrm{m}-1$

$=50-2-1$

$=47$ 
Diperoleh F tabel $=3,20$

Dapat dilihat bahwa $\mathrm{F}$ hitung $>\mathrm{F}$ tabel yaitu 28,182 > 3,20 ini berarti Ho di tolak dan H1 diterima atau terdapat hubungan linier secara bersama sama antara X1 dan $\mathrm{X} 2$ dengan $\mathrm{Y}$

\section{Cara kedua :}

Selain menggunakan angka F maka untuk menguji hipotesis juga dapat menggunakan angka signifikansi (sig) yang ada.

Dari output anova diperoleh signifikansi nya (sig) sebesar 0,000 .

Karena $0,000<0,05$ maka Ho ditolak dan H1 diterima artinya terdapat hubungan linier antara X1 dan X2 dengan Y.

Maka dapat disimpulkan dari hipotesis di atas sebagai berikut:

o Terdapat hubungan linier antara X1 dan $\mathrm{X} 2$ secara bersama-sama dengan $\mathrm{Y}$

o Terdapat pengaruh X1 dan X2 secara bersama-sama terhadap Y.

D.Pengaruh Kepemimpinan(X1) dan Motivasi Anak Asuh(X2) Secara Parsial Terhadap Kesejahteraan Sosial Anak Asuh (Y)

Untuk melihat adanya hubungan X1 dan $\mathrm{X} 2$ secara parsial terhadap Y digunakan Uji t atau menggunakan angka sig, jika angka sig $<0.05$ berarti signifikan (ada hubungan ) sedangkan untuk melihat besarnya pengaruh digunakan angka Beta atau Standardized Coefficients.

Tabel 4.4

Coefficients $^{a}$ pengaruh parsial variabel kepemimpinan (X1) dan motivasi anak asuh (x2) terhadap kesejahteraan sosial anak asuh

(Y)

\begin{tabular}{|c|c|c|c|c|c|}
\hline & $\begin{array}{r}\text { Unstan } \\
\text { ze } \\
\text { Coeffi }\end{array}$ & $\begin{array}{l}\text { ndardi } \\
\text { icients }\end{array}$ & $\left|\begin{array}{c}\text { Standardi } \\
\text { zed } \\
\text { Coefficien } \\
\text { ts }\end{array}\right|$ & & \\
\hline Model & B & $\begin{array}{l}\text { Std. } \\
\text { Error }\end{array}$ & Beta & $\mathrm{t}$ & $\begin{array}{l}\mathrm{Si} \\
\mathrm{g} .\end{array}$ \\
\hline 1 (Constant) & 14.540 & 7.934 & & $\begin{array}{r}1.83 \\
3\end{array}$ & .073 \\
\hline $\begin{array}{l}\text { KEPEMIMPIN } \\
\text { AN }\end{array}$ & .461 & .160 & .391 & $\begin{array}{r}2.88 \\
7\end{array}$ & .006 \\
\hline MOTIVASI & .352 & .115 & .413 & $\begin{array}{r}3.05 \\
3\end{array}$ & .004 \\
\hline
\end{tabular}

Sumber : Perhitungan SPSS

a. Hubungan dan besarnya pengaruh antara variabel kepemimpinan (X1) terhadap Kesejahteraan (Y)

\section{Hipotesis :}

Ho : Tidak terdapat hubungan linier antara X1 dengan Y

H1 : Terdapat hubungan linier antara X1 dengan $\mathrm{Y}$

Dari tabel Coefficien yang diperoleh dari SPSS didapat angka signifikansinya sebesar 
0,006 .

- Kerena 0,006 < 0,05 maka Ho ditolak dan H1 diterima artinya terdapat hubungan

linier antara X1 dengan Y.

- Besarnya pengaruh X1 ter ${ }^{1}{ }_{r \times 1 \times 2=0,687}{ }^{r}$ sebesar 0,391 atau sebesar 39,1c,

b. Hubungan dan besarnya pengaruh antara variabel motivasi anak asuh (X2) terhadap kesejahteraan sosial anak $\operatorname{asuh}(\mathrm{Y})$

\section{Hipotesis :}

Ho : Tidak terdapat hubungan linier antara X2 dengan Y

H1 : Terdapat hubungan linier antara X2 dengan $\mathrm{Y}$

Dari tabel Coefficient yang diperoleh dari SPSS didapat angka signifikansinya sebesar 0,004 .

- Kerena 0,004<0,05 maka Ho ditolak dan $\mathrm{H} 1$ diterima artinya terdapat hubungan linier antara X2 dengan Y.

- Besarnya pengaruh X2 terhadap Y sebesar 0,413 atau sebesar 41,3\%.

Dari pembahasan akhirnya didapat persamaan strukuturalnya sebagai berikut

$$
\mathrm{Y}=0,391 \mathrm{X}+0,413 \mathrm{X} 2+0,455 \xi
$$

\section{Gambar 4.1}

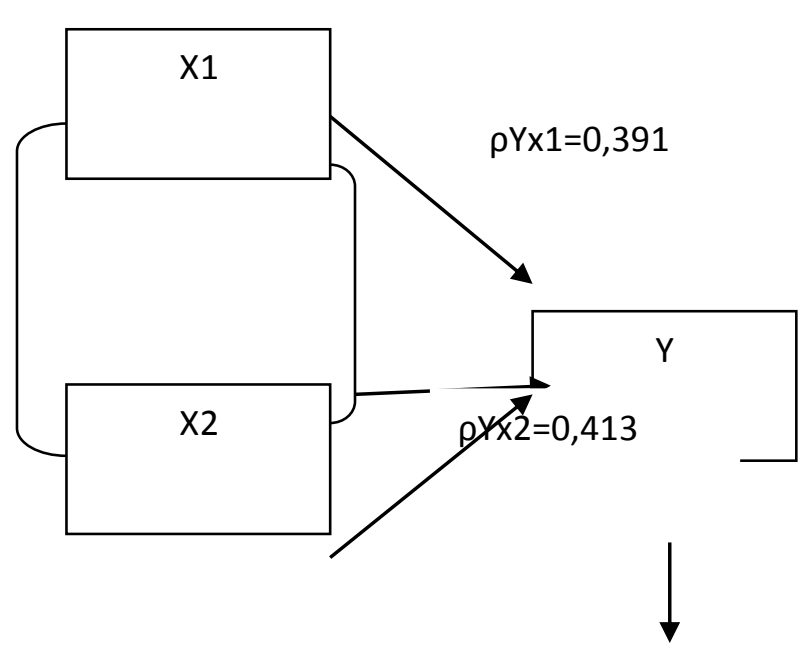

$\varepsilon=0,455$

\section{E. Pembahasan}

\section{Kepemimpinan (X1)}

Hasil tanggapan responden tentang kepemimpinan (X1) diperoleh rata-rata score sebesar 4,55 (tabel 4.5). Apabila skore tersebut ditransfomasikan ke dalam tabel 4.6 tentang kriteria penafsiran kondisi variabel penelitian, maka dapat dikatakan bahwa kepemimpinan dapat dikategorikan sangat baik. Kondisi seperti ini jelas merupakan hal yang diterapkan oleh Panti Asuhan Kurnia Asih, karena berefek kepada kesejahteraan sosial anak asuh.

Temuan ini sejalan dengan teori prinsip yang menjadi inti dari prilaku kepemimpinan menurut Anderson dalam 
Usman Husaini (2006:288), diantaranya sebagai berikut:

"Kepemimpinan, dalam artian yang lebih mendalam adalah pemahaman dan pemenuhan kebutuhan utama dari orang yang sedang kita pimpin/layani. Bagaimanapun peningkatan inovasi dan produktivitas dari tujuan yang akan dicapai, perlu juga diperhatikan kebutuhan tiap orang akan pengakuan, penghargaan, dan pencapaiannya. Untuk mendorong motivasi dan kepuasan."

Jadi kepemimpinan(X1) Panti Asuhan Kurnia Asih saat ini, dalam pengertian di atas telah faham dam mampu memenuhi kebutuhan utama dari anak asuhnya yang dipimpinnya, peningkatan inovasi dan produktivitas dari tujuan telah dicapainya, juga telah mampu memenuhi kebutuhan tiap anak asuhnya akan pengakuan, penghargaan dan pencapainya yang pada akhirnya anak akan temotivasi dan sejahtera. Kepemimpinan menurut pengertian di atas mempunyai korelasi dengan motivasi yang pada akhirnya menghasilkan kepuasan dalam hal kesejahteraan sosial anak asuh.

Semakin baik kepemimpinan menurut pengertian diatas seperti yang telah dijalankan di Panti Asuhan Kurnia Asih, semakin tinggi pula kesejahteraan yang akan didapatkan oleh anak asuhnya.

\section{Motivasi Anak Asuh (X2)}

Hasil tanggapan responden tentang Motivasi Anak Asuh (X2) diperoleh ratarata score sebesar 4,27 (tabel 4.15). Apabila skore tersebut ditransfomasikan ke dalam tabel 4.6 tentang kriteria penafsiran kondisi variabel penelitian, maka dapat dikatakan bahwa motivasi anak asuh dapat dikategorikan sangat baik. Kondisi seperti ini jelas merupakan hal baik yang diterapkan oleh Panti Asuhan Kurnia Asih, karena berefek kepada kesejahteraan sosial anak asuh.

Temuan ini sejalan dengan teori motivasi menurut Mc Cleilland dalam Usman Husaini (2006:237), diantaranya sebagai berikut:

"Motivasi berperastasi ialaih dorongan dari dalam diri untuk mengatasi segala tantangan dan hambatan dalam upaya mencapai tujuan. Motivasi afiliasi ialah dorongan untuk berhubungan dengan orang lain atau dorongan untuk memiliki sahabat-sebanyak-banyaknya.Motivasi berkuasa ialah dorongan untuk mempengaruhi orang lain agar tunduk kepada kehendaknya." 
"Motivasi adalah serangkaian sikap dan nilai-nilai yang mempengaruhi individu untuk mencapai hal yang spesifik atau rasa puas, sesuai dengan tujuan individu. Sikap dan nilai tersebut merupakan suatu yang tak dapat dilihat (invisible) yang memberikan kekuatan untuk mendorong individu bertingkah laku dalam mencapai tujuan (Rivai, 2005)

Jadi motivasi anak asuh (X2) di Panti Asuhan Kurnia Asih sesuai dengan pengertian di atas bahwa anak asuh telah berani memikul tanggung jawab sebagai konsekuensi usahanya untuk mencapai tujuan, sudah berani mengambil resiko yang sudah diperhitungkan, dan ingin kepuasan dari yang telah dikerjakan. Anak Asuh lebih suka bersama orang lain dari pada sendirian, lebih efektif apabila bekerjasama dengan orang lain juga sangat peka terhadap teman lainnya dalam hal kesulitan. Motivasi dapat mempengaruhi individu mencapai hal yang spesifik atau rasa puas, sesuai dengan tujuan individu mengandung makna bahwa motivasi anak asuh dapat mempengaruhi untuk mencapai rasa puas atau dengan kata lain sejahtera.

\section{Kesejahteraan Sosial Anak asuh(Y)}

Hasil tanggapan responden tentang kesejahteraan sosial anak asuh (Y) diperoleh rata-rata score sebesar $\mathbf{4 , 5 6}$ (tabel 4.24), skor tertinggi diantara variabel lannya. Apabila skore tersebut ditransfomasikan ke dalam tabel 4.6 tentang kriteria penafsiran kondisi variabel penelitian, maka dapat dikatakan bahwa motivasi anak asuh dapat dikategorikan sangat baik. Kondisi seperti ini jelas merupakan hal baik yang ada di Panti Asuhan Kurnia Asih.

Temuan ini sejalan menurut Undang undang RI Nomor 11,2009;2, diantaranya sebagai berikut:

"Kesejahteraan sosial adalah : kondisi terpenuhinya kebutuhan material, spiritual, dan sosial warga negara agar dapat hidup layak dan mampu mengembangkan diri, sehingga dapat melaksanakan fungsi sosialnya.(Undang-undang Republik Indonesia Nomor 11,2009:2)"

Juga menurut teori hierarki kebutuhan Maslow terdapat lima tingkatan kebutuhan, dari kebutuhan manusia yang paling rendah sampai kebutuhan manusia yang paling tinggi, yaitu:

a. Kebutuhan Fisiologikal (Fisiological need) merupakan kebutuhan dasar atau kebutuhan yang paling rendah dari manusia. Sebelum seseorang menginginkan kebutuhan di atasnya. 
Kebutuhan ini harus dipenuhi terlebih dahulu agar dapat hidup secara normal.

Contoh kebutuhan ini adalah kebutuhan akan sandang, pangan, papan, istirahat, rekreasi, tidur dan hubungan seks. Untuk memenuhi kebutuhan ini manusia biasanya berusaha keras untuk mencari rezeki.

b. Kebutuhan Keselamatan (Safety Needs, Security Needs)

Setelah kebutuhan fisiological terpenuhi, maka muncul kebutuhan baru yang diinginkan manusia, yaitu kebutuhan akan keselamatan atau rasa aman. Contoh kebutuhan ini antara lain menabung, perlindungan orang tua asuh dll.

c. Kebutuhan Berkelompok (Social Needs)

Setelah kebutuhan keselamatan atau rasa aman terpenuhi maka muncul pula kebutuhan baru yang diinginkan manusia, yaitu kebutuhan hidup berkelompok, bergaul, bermasyarakat, ingin mencintai dan dicintai, serta ingin dimiliki dan memiliki. Contoh kebutuhan ini antara lain membina keluarga, bersahabat, bergaul bercinta, menikah dan mempunyai anak, bekerja sama, menjadi anggota organisasi. Untuk memenuhi kebutuhan ini biasanya manusia berdoa dan berusaha unuk memenuhinya. d. Kebutuhan Penghormatan (Esteem Needs) Setelah kebutuhan berkelompok terpenuhi, maka muncul kebutuhan baruyang diinginkan manusia, yaitu kebutuhan akan penghormatan atau ingin berprestasi. Contoh kebutuhan ini antara lain ingin mendapatkan ucapan terima kasih, ucapan selamat jika berjumpa, menunjukkan rasa hormat, mendapatkan tanda penghargaan (hadiah). Untuk memenuhi kebutuhan ini biasanya manusia berdoa minta ditinggikan derajatnya melalui salat tahajud dan berusaha memenuhi aturan seperti jika ingin dihormati orang lain maka kita harus menghormati orang lain.

e. Kebutuhan aktualisasi diri (Self Actualization Needs)

Setelah kebutuhan penghormatan terpenuhi, maka muncul kebutuhan baru yang diinginkan manusia, yaitu kebutuhan akan aktualisasi diri atau realisasi diri atau pemenuhan kepuasan atau ingin berprestise. Contoh kebutuhan ini antara lain memiliki sesuatu bukan hanya karena fungsi tetapi juga gengsi, mengoptimalkan potensi dirinya secara kreatif dan inovatif, ingin mencapai taraf hidup yang serba sempurna atau derajat setinggi-tingginya, melakukan pekerjaan yang kreatif, ingin pekerjaan yang 
menantang. Untuk memenuhi kebutuhan ini biasanya manusia berusaha dan berdoa untuk memenuhi. (Usman Husaini,2006:223)

Jadi di Panti Asuhan Kurnia Asih bahwa kesejahteraan sosial anak asuh, sebagian telah memenuhi kriteria menurut Undang-undang RI No 11 Tahun 2011 dan teori Maslow, yang manyatakan bahwa anak asuh telah sejahtera sesuai dengan tingkatan kebutuhannnya bail materill, sprituil dan sosialnya.

\section{H. Keterbatasan}

Untuk menyelasaikan penelitian ini kami menghadapi beberapa keterbatasan, sehingga dalam penyajiannya masih banyak kekurangan yang akan ditemui, keterbatasan tersebut di antaranya:

1. Generalisasi lemah, dengan kata lain hasil penelitian ini tidak dapat digunakan pada objek / tempat lain melainkan hanya dapat digunakan pada objek penelitian ini saja. Karenanya untuk selnjutnya sebaiknya memperluas generalisasi dengan melakukan penelitian ditempat yang berbeda.

2. Koefisien determinasi untuk kesejahteraan sosial anak asuh sebesar $54,5 \%$, sehingga terdapat kemungkinan ada faktor-faktor lain yang mempengaruhi kesejahteraan sosial anak asuh yakni sebesar $\mathbf{4 4 , 5 \%}$. Karenanya untuk selanjutnya perlu mempertimbangkan faktorfaktor lain yang dapat mempengaruhi kesejahteraan sosial anak asuh.

\section{KESIMPULAN}

Beberapa kesimpulan yang dapat ditarik dari penelitian yang telah dilakukan adalah :

1. Terdapat pengaruh positif antara kepemimpinan (x1) terhadap kesejahteraan sosial anak asuh (y) di Panti Asuhan Kurnia Asih, sebesar $0,391.39,1 \%$

2. Terdapat pengaruh positif antara motivasi anak asuh (x2) terhadap kesejahteraan sosial anak asuh (y) di Panti Asuhan Kurnia Asih, sebesar 0,413 , atau $41,3 \%$

3. Terdapat pengaruh positif antara kepemimpinan (x1) dan motivasi anak asuh (x2) secara bersama-sama terhadap kesejahteraan sosial anak asuh (y) di Panti Asuhan Kurnia Asih, sebesar 0,54 atau 54,5\%

\section{SARAN}

1. Anjuran untuk pimpinan-pimpinan panti di Bandung meniru 
kepemimpinan transformasional, karena sangat cocok diterapkan diorganisasi sosial seperti panti asuhan,

2. Anjuran untuk pimpinan-pimpinan panti di Bandung dapat memotivasi anak asuhnya dengan gaya kepemimpinan transformasionalnya.

3. Anjuran untuk pimpinan-pimpinan panti di Bandung dapat mensejahterakan anak asuhnya dalam pangan, sandang, papan kesehatan dan pendidikannya, nahkan disekolahkan sampai sekolah tinggi sampai mereka mendiri dan tidak menjadi beban bagi sesamanya.

\section{DAFTAR PUSTAKA}

Istijanto,(2005), Riset Sumber Daya Manusia, Jakarta.

Usman, Husaini,(2006), Manajemen Teori,Praktik dan Riset Pendidikan, Jakarta.

Yuli, Budi Cantika (2005), Manajemen SDM, UMM Press, Malang.

Rivai,(2005), Manajemen SDM, Jakarta.

Husen Umar,(2004), Riset Sumber Daya Manusia, Gramedia Pustaka Utama. Jakarta
Andrson,(1998),Transforming

Leadership, NY Prentice Interection,Ohio.

Stogdill,(1974), Leadership and structures of personal interaction, Ohio.

Yukl,(1987), Leadership in Organization,NY Prentice Hill Corp..NY

Kartono, Kartini, (1994), Pemimpin dan Kepemimpinan. PT. Raja Grafindo Persada, Jakarta.

Dokumen-dokumen Negara :

Undang-undang RI Nomor 11 tentang kesejeaheraan sosial,(2009), Jakarta.

Undang-undang No4 tahun 1979 tentang kesejahteraan anak,(1979), Jakarta.

Standar Nasional pengasuhan untuk Lembaga Kesejahteraan Sosial Anak,(2011), Kemensos. Jakarta.

Pedoman Lembaga Kesejahteraan Sosial Anak,(2011), Kemensos, Jakarta Sosial dalam PKSA,(2011), Jakarta.

Tesis:

Bikku Darma Suuuryo,(2010) Pengaruh Gaya Kepemimpinan Transformasional, Budaya Organisasi dan Inovasi terhadap Kinerja (studi pada Panti asuhan di Kota Tomohon dan Kabupaten Minahasa), Universitas Brawijaya Malang.

Riyanta Didik,(2009), Pengaruh Profil Kepemimpinan dan Lingkungan terhadap 
Sistem Kepemimpinan di Panti asuhan Yatim

Piatu dan Du'afa Muhammadiyah

Prambanan, Sleman. 